\title{
Deskripsi Jenis Kesalahan dalam Menyelesaikan TIMSS-Based Test Ditinjau dari Kemampuan Awal pada Siswa SMP
}

\author{
Alimuddin $^{1, \text { a) }}$, Ilham ${ }^{1, \mathrm{~b})}$, dan Jubaedah ${ }^{1, \mathrm{c})}$ \\ ${ }^{1}$ Jurusan Matematika, Fakultas MIPA, Universitas Negeri Makassar \\ a)alimuddin@gmail.com \\ b)ilhamminggi@gmail.com \\ c)jedha011@gmail.com
}

\begin{abstract}
Abstrak. Penelitian ini bertujuan untuk mengetahui jenis-jenis kesalahan yang dilakukan oleh siswa berkemampuan awal matematika tinggi dan kemampuan awal matematika rendah dalam menyelesaikan soal geometri berbasis TIMSS untuk domain kognitif mengaplikasikan (applying) dan penalaran (reasoning). Jenis penelitian ini adalah penelitian kualitatif dengan menggunakan pendekatan deskriptif. Subjek penelitian sebanyak 2 orang dengan 1 orang berkemampuan awal matematika tinggi dan 1 orang berkemampuan awal matematika rendah dari siswa kelas VIII SMP. Instrumen penelitian menggunakan terdiri atas tes matematika berbasis TIMSS yang dikhususkan pada konten geometri domain kognitif aplikasi dan penalaran serta pedoman wawancara. Kesalaan yang dianalisis dikategorikan menggunakan kategori kesalahan Newman. Hasil penelitian menunjukkan bahwa: (1) Untuk kategori soal mengaplikasikan (applying), siswa kemmpuan awal matematika tinggi tidak mengalami kesalahan, sedangkan siswa berkemampuan matematika rendah mengalami jenis kesalahan transformation, process skills, dan encoding. (2) Untuk kategori soal penalaran (reasoning), siswa berkemampuan awal tinggi mengalami kesalahan tipe transformation, process skills, dan encoding sedangkan siswa berkemampuan awal rendah mengalami kesalahan tipe comprehension, transformation, process skills, dan encoding.

Kata kunci : Kesalahan, Soal Matematika TIMSS, Domain Kognitif applying dan reasoning konten geometri, Kemampuan Awal, Kriteria Newman.
\end{abstract}

\begin{abstract}
This study aims to know the types of errors committed by students with high initial mathematical abilities and low initial mathematical abilities in solving TIMSS-based geometric questions for the cognitive domain of applying and reasoning. The type of this research is qualitative research using a descriptive approach. The research subjects as many as 2 people with of 1 people with early mathematical abilities and 1 people with low initial mathematical abilities from class VIII SMP. The research instrument consists of a TIMSS-based mathematical test devoted to the geometry content of the cognitive domain application and reasoning and interview guidelines. The difficulties analyzed were categorized using the Newman error category. The results of this research showed that: (1) For the category of applying, students with high initial mathematical abilities did not have errors, while students with low mathematical abilities had types of transformation errors, process skills, and encoding. (2) For the category of reasoning, the errors type of the students with high initial mathematical abilities are transformation, process skills, and encoding while students with low mathematical abilities had comprehension, transformation, process skills, and encoding errors.
\end{abstract}

Keywords: Errors, TIMSS Mathematical Questions, Cognitive Domain applying and reasoning content geometry, Initial Capability, Newman's Criteria.

\section{PENDAHULUAN}

Saat ini, evaluasi pendidikan yang diterapkan Pemerintah Indonesia untuk menilai kemampuan matematika dan sains siswa adalah salah satunya Ujian Nasional (UN). Sedangkan dalam skala 
internasionalterdapat dua assesmen utama yang merupakan bentuk evaluasi untuk mengukur kemampuan matematika dan sains siswa suatu negara yaitu, PISA (Programme for International Student Assesment)dan TIMSS (Trend in International Mathematics and Science Study).

TIMSS dilakukan dalam rangka membandingkan prestasi Matematika dan IPA siswa kelas 8 dan kelas 4 di beberapa negara di dunia. TIMSS diselenggarakan secara rutin setiap 4 tahun sekali bertujuan untuk melihat bagaimana kurikulum yang dicanangkan oleh setiap negara diimplementasikan dan capaian siswa khususnya pada bidang matematika dan sains. Kerangka umum untuk asesmen matematika TIMSS 2015 memiliki 2 dimensi, satu dimensi berkaitan dengan konten, sedangkan dimensi yang lain berkaitan dengan kognisi. Dalam dimensi konten, ada 3 ranah dalam matematika untuk kelas 4 dan ada 4 ranah untuk kelas 8 . Selain itu, ada 3 ranah kognitif untuk masing-masing area kurikulum (kelas 4 dan 8): mengetahui (knowing), menggunakan (applying), dan penalaran (reasoning)

Pertama kali diselenggarakan pada tahun 1995, Indonesia baru berpartisipasi pada studi TIMSS sejak tahun 1999. Pencapaian prestasi belajar siswa Indonesia di bidang matematika pada studi TIMSS masih jauh dari predikat memuaskan.Sejak mengikuti TIMSS 1999 sampai TIMSS 2011 untuk tingkat kelas VIII dan TIMSS 2015 untuk tingkat kelas IV , Indonesia selalu mendapatkan skor di bawah skor rata-rata internasional. Berikut Tabel 1 menunjukkan capaian prestasi Indonesia selama mengikuti TIMSS:

TABEL 1. Capaian Prestasi Indonesia dalam mengikuti TIMSS (Gunawan \& Salim, 2010)

\begin{tabular}{cccccc}
\hline Tahun & Peringkat & Negara & Skor & Rata-Rata & Kelas \\
\hline 1999 & 34 & 38 & 403 & 487 & VIII \\
2003 & 34 & 45 & 422 & 467 & VIII \\
2007 & 36 & 49 & 397 & 500 & VIII \\
2011 & 38 & 42 & 386 & 500 & VIII \\
2015 & 45 & 50 & 397 & & IV \\
\hline
\end{tabular}

Jika dikaji lebih rinci, capaian siswa Indonesia selama mengikuti TIMSS untuk dimensi kognitif pada domain mengaplikasikan (applying) hanya mempunyai rata-rata $23 \%$ dan domain penalaran (reasoing) 17\% pada tahun 2011 (Rosnawati, 2013). Hal ini menunjukkan bahwa kemampuan pengaplikasian serta penalaran siswa Indonesia masih rendah. Sejalan dengan penelitian Nurkhasanah (2016) yang menemukan bahwa dalam menyelesaikan soal TIMSS, siswa banyak mengalami kesalahan. Salah satu faktor penyebabnya adalah lemahnya penalaran siswa dalam memahami soal-soal TIMSS.

Sementara dari segi konten, capaian siswa Indonesia mengikuti TIMSS pada tahun 2011 hanya $24 \%$ pada konten bilangan, 22\% pada konten aljabar, 24\% pada konten geometri dan $29 \%$ pada konten data dan peluang (Rosnawati, 2013). Capaian siswa indonesia tersebut menunjukkan bahwa kesulitan siswa dalam memecahkan soal geometri cukup tinggi, dengan hanya $24 \%$ yang diperoleh. Sejalan dengan Herlambang (2013) yang mengatakan bahwa geometri termasuk materi yang sulit untuk dikuasai setelah pecahan dan soal matematika berbentuk cerita.

Penelitian ini bertujuan untuk mendapatkan deskripsi jenis kesalahan siswa dalam menyelesaikan soal berbasis TIMSS ditinjau dari kemampuan awal. Soal TIMSS yang diangkat yaitu domain kognitif mengaplikasikan dan penalaran. Penelitian ini berfokus pada domain konten geometri. Dalam menganalisis kesalahan, menggunakan prosedur Newman Error Analysis.

Newman mengembangkan model yang dikenal sebagai Newman Error Hierarchy yang terdiri dari lima kategori kesalahan yaitu membaca $(R)$, pemahaman $(C)$, transformasi $(T)$, keterampilan proses $(P)$, dan penulisan jawaban $(E)$. Beberapa peneliti pernah menggunakan prosedur Newman Error Analysis untuk meneliti terkait kesalahan siswa dalam menyelesaikan soal kontektual (Wijaya, Abdullah, Abidin, \& Ali. 2014). Penelitian ini juga menggunakan 
prosedur Newman Error Analysis untuk menganalisis kesalahan dalam memecahkan masalah pada konteks nyata dan bernalar seperti soal-soal TIMSS.

\section{KAJIAN PUSTAKA}

\section{TIMSS (Trend in International Mathematics and Science Study)}

TIMSS adalah suatu kegiatan yang diselenggarakan oleh International Association for the Evaluation of Educational Achievement (IEA) yang bergerak di bidang penilaian dan pengukuran pendidikan yang berkedudukan di negeri Belanda. IEA melalui studinya dalam TIMSS menganggap bahwa kurikulum mempunyai makna yang luas. Dengan berdasar pada kurikulum sekolah di seluruh dunia, TIMSS selanjutnya menginvestigasi 3 level. Ketiga level kurikulum yang didefinisikan oleh TIMSS sebagai model IEA itu adalah: intended curriculum (Kurikulum Kebijakan Nasional), implemented curriculum (Kurikulum Tingkat Pelaksanaan), dan attained curriculum (Kurikulum Tingkat Pencapaian).

Tujuan TIMSS adalah untuk mengukur prestasi matematika dan ilmu pengetahuan alam siswa kelas IV serta kelas VIII di negara negara peserta. Bagi Indonesia, manfaat yang dapat diperoleh antara lain untuk mengetahui posisi prestasi siswa Indonesia bila dibandingkan dengan prestasi siswa di negara lain dan faktor -faktor yang mempengaruhinya. Oleh karena itu, hasil studi ini diharapkan dapat digunakan sebagai masukan dalam perumusan kebijakan untuk peningkatan mutu pendidikan. Hasil penilaian TIMSS dalam matematika dikelompokkan dalam empat tingkatan, yaitu "Advance "standar mahir (625), "High" standar tinggi (550), "Intermediate" standar menengah (475), dan "Low" standar rendah (400).

\section{Domain TIMSS}

Dasar penilaian prestasi matematika dan sains dalam TIMSS dikategorikan ke dalam dua domain, yaitu domain konten dan domain kognitif dengan memperhatikan kurikulum yang berlaku di negara yang bersangkutan. Dalam dimensi konten, ada 3 ranah dalam matematika untuk kelas 4 dan ada 4 ranah untuk kelas 8.

Selain itu, ada 3 ranah kognitif untuk masing-masing area kurikulum (kelas 4 dan 8): mengetahui (knowing), menggunakan (applying), dan penalaran (reasoning). Kedua dimensi dan ranahnya merupakan fondasi asesmen matematika. Ranah konten mendefinisikan materi tertentu yang dicakup oleh asesmen, dan ranah kognitif mendefinisikan himpunan keterampilan yang diharapkan dari siswa ketika mereka terlibat dengan konten tersebut. Berikut gambar 3 terkait mengenai dimensi dari TIMSS: 


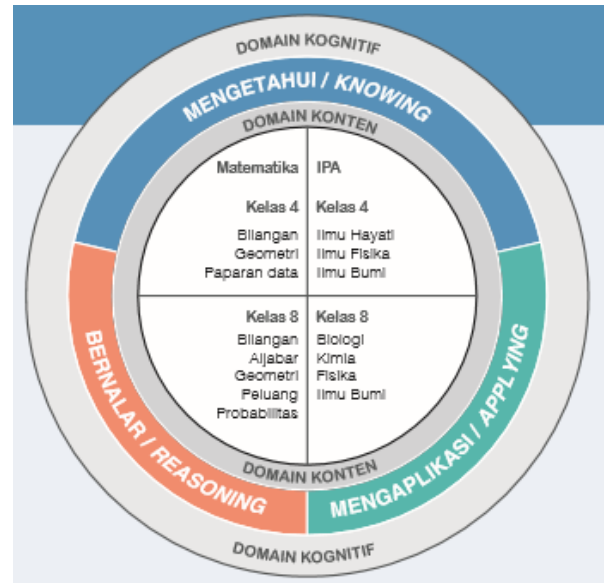

GAMBAR 1. Dimensi TIMSS (Sumber: Pusat Penilaian Pendidikan, Badan Penelitian dan Pengembanngan (2015))

\section{Newman Error Hierarchy}

Menurut Kamus Besar Bahasa Indonesia, kesalahan adalah perihal salah, kekeliruan, kealpaan sehingga jika kesalahan itu dihubungkan dengan objek dasar matematika menurut Soedjadi (Laeli, 2017) kesalahan yang dimaksud adalah Kesalahan Fakta , Kesalahan Konsep, Kesalahan Prinsip, Kesalahan Operasi. Melihat dari beberapa pendapat para ahli mengenai jenis-jenis kesalahan yang dilakukan oleh siswa dalam mengerjakan soal, dalam penelitian ini menggunakan tipe-tipe kesalahan menurut Newman. Menurut Newman (Singh,2010), setiap siswa yang ingin menyelesaikan masalah matematika, mereka harus bekerja melalui lima tahapan berurutan yaitu:

1. Kesalahan Membaca (reading errors)

Kesalahan membaca soal adalah suatu kesalahan yang disebabkan karena siswa tidak bisa: 1) mengenal/membaca simbol-simbol yang ada pada soal; 2) mengerti makna dari simbol pada soal tersebut; atau 3) memaknai kata kunci yang terdapat pada soal tersebut. Tipe kesalahan membaca soal biasa disebut juga dengan kesalahan tipe R.

2. Kesalahan Memahami Masalah (comprehension errors)

Kesalahan memahami masalah adalah suatu kesalahan yang disebabkan karena siswa tidak bisa: 1) memahami arti keseluruhan dari suatu soal; 2) menuliskan dan menjelaskan apa yang diketahui dari soal tersebut; atau 3) menuliskan dan menjelaskan apa yang ditanya dari soal tersebut. Tipe kesalahan memahami masalah biasa disebut juga dengan kesalahan tipe $\mathrm{C}$.

3. Kesalahan Transformasi (transfomation errors)

Kesalahan transformasi adalah suatu kesalahan yang disebabkan karena siswa tidak bisa: 1) menentukan rumus yang akan digunakan untuk menyelesaikan soal tersebut; 2) menentukan operasi matematika atau rangkaian operasi untuk menyelesaikan permasalahan dalam soal tersebut dengan tepat; atau 3) mengidentifikasi operasi, atau serangkaian operasi. Tipe kesalahan transformasi biasa disebut juga dengan kesalahan tipe T.

4. Kesalahan Keterampilan Proses (process skills errors)

Kesalahan keterampilan proses adalah suatu kesalahan yang disebabkan karena siswa tidak bisa: 1) mengetahui proses/algoritma untuk menyelesaikan soal meskipun sudah bisa menentukan rumus dengan tepat; atau 2) menjalankan prosedur dengan benar meskipunsudah mampu menentukan operasi matematika yang digunakan dengan tepat.3) mengerjakan runtutan penyelesaian soal dengan benar. Kesalahan ini merupakan suatu kesalahan yang dilakukan siswa dalam proses perhitungan. Siswa mampu memilih operasi matematika apa yang harus digunakan, tapi ia tidak mampu menghitungnya 
dengan tepat.Tipe kesalahan keterampilan proses biasa disebut juga dengan kesalahan tipe $\mathrm{P}$

5. Kesalahan Penulisan Jawaban (encoding errors)

Kesalahan penulisan jawaban adalah suatu kesalahan yang disebabkan karena siswa tidak bisa: 1)menuliskan jawaban yang ia maksudkan dengan tepat sehingga menyebabkan berubahnya makna jawaban yang ia tulis; 2) mengungkapkan solusi dari soal yang ia kerjakan dalam bentuk tertulis yang dapat diterima; atau 3) menuliskan dengan benar jawaban akhirnya atau mendapatkan jawaban akhir yang benar atau menuliskan satuannya. Tipe kesalahan penulisan jawaban biasa disebut juga dengan kesalahan tipe E.

\section{Indikator Klasifikasi Jenis Kesalahan Siswa dalam Menyelesaikan Soal Matematika berbasis TIMSS Berdasarkan Newman Error Hierarchy}

Berdasarkan teori tentang Newman Error Hierachy dan deskripsi indikator domain kognitif, dikembangkan beberapa indikator untuk menunjukkan jenis kesalahan siswa dalam menyelesaikan soal TIMSS. Indikator klasifikasi jenis kesalahan siswa dalam menyelesaikan soal matematika berbasis TIMSS berdasarkan Newman Error Hierarchy:

TABEL 2. Indikator kesalahan siswa dalam menyelesaikan soal TIMSS

\begin{tabular}{|c|c|}
\hline Jenis Kesalahan & Indikator Kesalahan \\
\hline $\begin{array}{l}\text { Reading Errors } \\
\text { (R) }\end{array}$ & $\begin{array}{l}\text { - Siswa tidak mengenal bahasa/simbol/notasi yang ada pada } \\
\text { soal. } \\
\text { - Siswa tidak mengerti makna dari bahasa/simbol/ notasi yang } \\
\text { ada pada soal }\end{array}$ \\
\hline $\begin{array}{l}\text { Comprehension } \\
\text { Errors (C) }\end{array}$ & $\begin{array}{l}\text { - Siswa tidak bisa memahami arti keseluruhan dari soal. } \\
\text { - Siswa tidak mampu menafsirkan apa yang diminta untuk } \\
\text { dikerjakan. } \\
\text { - Siswa tidak bisa memahami arti keseluruhan soal (misal, } \\
\text { menggunakan seluruh informasi pada soal, atau mengabaikan } \\
\text { informasi penting dalam soal) }\end{array}$ \\
\hline $\begin{array}{l}\text { Transfomation } \\
\text { Errors (T) }\end{array}$ & $\begin{array}{l}\text { - Siswa cenderung secara langsung menggunakan suatu prosedur } \\
\text { matematika (seperti formula, algoritma) tanpa menganalisa } \\
\text { terlebih dahulu. } \\
\text { - Siswa menggunakan prosedur matematika/ konsep yang tidak } \\
\text { relavan pada soal } \\
\text { - Siswa lebih fokus pada keadaan nyata grafik/gambar daripada } \\
\text { karakteristik grafik/gambar } \\
\text { - Siswa tidak bisa menentukan prosedur/rumus yang akan } \\
\text { digunakan. }\end{array}$ \\
\hline $\begin{array}{l}\text { Process Skills } \\
\text { Errors (P) }\end{array}$ & $\begin{array}{l}\text { - } \text { kesalahan dalam operasi hitung } \\
\text { - Siswa salah dalam menuliskan tanda atau simbol matematika } \\
\text { - Siswa salah dalam mengerjakan runtutan penyelesaian soal }\end{array}$ \\
\hline $\begin{array}{l}\text { Encoding Errors } \\
\text { (E) }\end{array}$ & $\begin{array}{l}\text { - Siswa tidak mampu menginterprestasikan dengan benar dan } \\
\text { mengungkapkan solusi matematis } \\
\text { - Siswa tidak menuliskan dengan benar jawaban akhirnya atau } \\
\text { mendapatkan jawaban akhir yang salah atau tidak menuliskan } \\
\text { satuannya. }\end{array}$ \\
\hline
\end{tabular}




\section{METODE PENELITIAN}

Penelitian ini adalah penelitian Kualitatif dengan menggunakan pendekatan deskriptif. Subjek penelitian ini adalah 2 orang siswa kelas VIII SMP yang masing dengan satu orang siswa berkemampuan awal matematika tinggi dan satu orang siswa berkemampuan matematika rendah. Penetapan subjek penelitian ini berdasarkan hasil tes kemampuan awal yang diberikan. Berikut kategori kemampuan awal menurut menurut Depdiknas (2006), kategori tersebut antara lain:

1. Kategori siswa dengan kemampuan awal tinggi (T) $(80 \leq x \leq 100)$

2. Kategori siswa dengan kemampuan awal sedang $(65 \leq x<80)$, dan

3. Kategori siswa dengan kemampuan awal rendah $(x<65)$.

Rincian masing-masing subjek yang terpilih disajikan dalam Tabel 3:

TABEL 3. Penetapan Subjek Penelitian

\begin{tabular}{cccc}
\hline No & Kemampuan Awal & Skor Tes & Kode Siswa \\
\hline 1. & Tinggi & 84 & S1a \\
2. & Rendah & 44 & S2b \\
\hline
\end{tabular}

Siswa yang telah dikelompokkan, kemudian diberikan soal-soal matematika berbasis TIMSS materi geometri. Setelah itu, siswa tersebut diwawancara terkait dengan jawaban yang sudah mereka tuliskan dan menganalisis kesalahan yang mereka lakukan.

Teknik Pengumpulan data dalam penelitian ini meliputi: (1) Tes kemampuan awal matematika, (2) Tes soal matematika berbasis TIMSS, dan (3) Wawancara. Tes kemampuan matematika diberikan untuk mengetahui pemahaman awal siswa terhadap materi geometri guna untuk mengambil subjek penelitian. Setelah pemberian tes kemampuan awal, kemudian dilakukan pengkategorian kemampuan matematika siswa berdasarkan nilai hasil tes kemampuan awal yang diperoleh dan diurutkan dari nilai yang tertinggi ke yang terendah. Selanjutnya memberikan soal matematika berbasis TIMSS kepada masing-masing subjek. Tes soal berbasis TIMSS yang dimaksud dalam penelitian ini adalah soal-soal matematika yang berkaitan dengan pokok pelajaran geometri yang diuji pada penilaian TIMSS pada kontes literasi matematika tingkat SMP Kelas VIII dimana terdiri dari domain kognitif mengaplikasikan dan penalaran untuk konten geometri. Kemudian, mengidentifikasi jenis kesalahan berdasarkan hasil tes soal TIMSSyang dilakukan oleh subjek yang terpilih, yang selanjutnya setiap subjek tersebut diwawancarai.

Instrumen terdiri dari soal tes kemampuan awal, soal maematika berbasis TIMSS dan pedoman wawancara yang digunakan telah divalidasi oleh 2 orang validator. Data yang dikumpul dianalisis dengan menggunakan teknik analisis deskriptif-kualitatif. Didalam analisis data kualitatif terdapat tiga alur kegiatan yang terjadi secara bersamaan. Aktivitas dalam analisis data yaitu: 1) Kondensasi Data dimana menggolongkan, membuang yang tidak perlu, dan mengorganisasikan data mentah yang diperoleh dari lapangan. 2) Penyajian Data yakni pengorganisasian, penyatuan dari infomasi yang memungkinkan penyimpulan dan aksi dalam hal ini pengklasifikasian dan identifikasi jenis kesalahan siswa dalam menyelesaian soal berbasis TIMSS. 3) Penarikan Kesimpulan yaitu dilakukan berdasarkan hasil analisis data yang telah dikumpulkan melalui hasil tes dan rekaman wawancara. 


\section{HASIL DAN PEMBAHASAN}

\section{Domain Kognitif Mengaplikasikan (Applying)}

Soal TIMSS domain kognitif mengaplikasikan yang diujikan kepada setiap subjek yaitu mencari derajat tempuh jarum jam untuk rentang waktu tertentu. Soal tersebut bertujuan untuk mengetahui apakah subjek paham mengenai hubungan antara satuan besar sudut dan satuan waktu. Sehingga, pemahaman yang dimiliki dapat diaplikasikan dalam menyelesaikan soal.

Soal 1.

Berapa derajat yang ditempuh jarum menit jam, dari jam 06:20 sampai 08:00
pada hari yang sama?
A. $680^{\circ}$
B. $600^{\circ}$
C. $540^{\circ}$
D. $420^{\circ}$

Pada soal 1, subjek diminta untuk mencari berapa derajat yang ditempuh jarum menit jam dari jam 06.20 sampai 08.00 di hari yang sama. Untuk menyelesaikan soal, siswa dapat mencari terlebih dahulu selisih waktu dari pukul 06.20 sampai 08.00. Kemudian mencari derajat tempuh jarum menit jam dari selisih waktu yang diperoleh.

\section{Subjek Kemampuan Awal Matematika Tinggi (S1a)}

Dalam menyelesaikan soal TIMSS dengan domain kognitif mengaplikasikan, S1a tidak mengalami kesalahan.

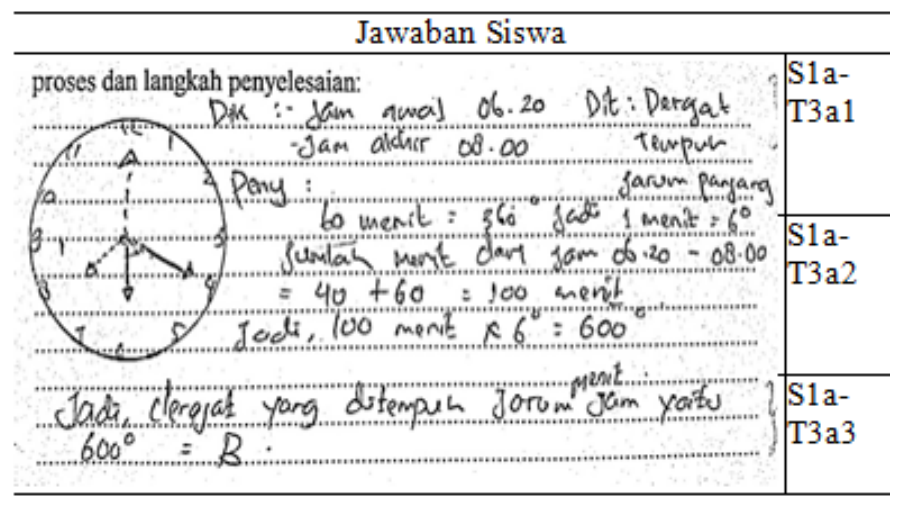

GAMBAR 2. Paparan hasil tes soal TIMSS untuk subjek S1a

Pada Gambar 2, terlihat S1a sudah mengerti makna simbol dan memahami arti dari keseluruhan soal (S1b-T3a1). S1a sudah menuliskan apa yang diketahui dan ditanyakan dengan tepat. S1a juga menggunakan operasi yang sudah tepat (S1b-T3a2). Hal ini dipertegas pada Transkip 1:

\section{TRANSKIP 1}

$P$

S1a-W3a3

$P$

S1a-W3a4
Wah, iya dek. Terus bagaimana caranya selesaikan?

Kan derajat yang dicari kak derajat dari yang ditempuh jarum jam, jadi harus ki tau berapa derajat permenitnya biar nanti ku kali mi dengan jumlah menit dari jam 06.20 sampai 08.00. kan ditau memang ji kak kalau 1 putaran jarum panjang sama dengan 60 menit terus 1 putaran lagi sama dengan $360^{\circ}$, jadi 60 menit sama dengan $360^{\circ}$, sehingga 1 menit sama dengan $6^{\circ}$, Saya bagi 60 ki kakk.

Oh iya dek, terus bagaimana lagi?

Terus kak saya cari mi berapa menit dari jam 06.20 sampai 08.00, itu kan jumlahnya 100 menit, dari 40+60. Kemudian yang 100menit itu saya kali 
mi dengan $6^{\circ}$ tadi karna 1 menit sama dengan $6^{\circ}$, jadi kalau 100 menit itu derajatnya $100 \times 6^{\circ}=600^{\circ}$. Jadi jawabannya $600^{\circ}$ yaitu $B$

Pada Transkip 1, S1a mencari terlebih dahulu berapa derajat permenitnya dengan menggunakan persamaan 60 menit $=360^{\circ}$ sehingga memperoleh 1 menit $=6^{\circ}$. Kemudian mencari waktu (menit) yang ditempuh dari 06.20 sampai 08.00. S1a memperoleh $40+60=100$ menit. Selanjutnya S1a mengalikan 100 menit dengan $6^{\circ}$ untuk memperoleh derajat tempuh dari jarum menit jam tersebut. Hal tersebut menegaskan bahwa S1a sudah bisa menentukan operasi matematika atau rangkaian operasi untuk menyelesaikan permasalahan dalam soal tersebut dengan tepat (S1a-W3a3). Prosedur yang dijalankan pun untuk menyelesaikan soal sudah benar (S1a-W3a4)), sehingga jawaban yang diperoleh sudah benar.

\section{Subjek Kemampuan Awal Matematika Rendah (S2b)}

Dalam menyelesaikan soal TIMSS dengan domain kognitif mengaplikasikan, S2b mengalami beberapa jenis kesalahan kesalahan.

Gambar 3 memperlihatkan bahwa dalam menyelesaikan soal, S2b terlebih dahulu menghitung selisih waktu dari pukul 06:20 sampai 08:00 dan memperoleh 1 jam 40 menit. Kemudian subjek mencari derajat tiap waktu yang diperoleh. Namun operasi yang digunakan untuk menyelesaikan masalah tersebut belum tepat ( S2b-T3a2). Hal tersebut dikonfirmasi pada Transkip 2.

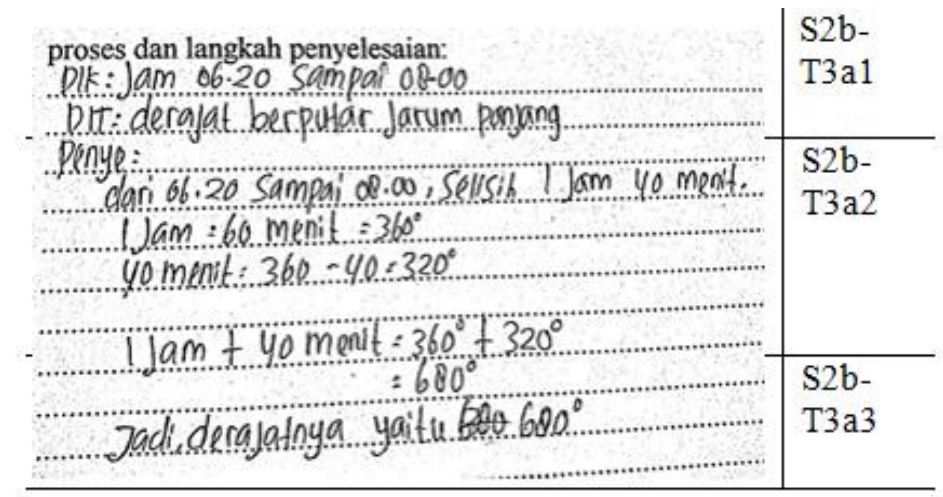

GAMBAR 3. Paparan hasil tes soal TIMSS untuk subjek S2b

\section{TRANSKIP 2}

$S 2 b-W 3 a 4$

$P$

$S 2 b-W 3 a 5$
Terus kak kan satu jam itu sama dengan 60 menit $=360^{\circ}$, jadi 1 jamnya sudahmi kak, tinggal 40 menitnya

Bagaimana dek dengan yang itu?

Terus kak yang 40 menit $=360^{\circ}-40=320^{\circ}$, jadi ku tambah mi kak. $360^{\circ}+$ $320^{\circ}=680^{\circ}$

Transkip 2 menunjukkan S2b belum tepat dalam prosedur mencari derajat tempuh untuk waktu 40 menit. S2b hanya mengurangkan 360-40=320 (S2b-W3a5). Strategi yang digunakan belum tepat dalam memecahkan masalah. S2b cenderung secara langsung menggunakan suatu prosedur matematika tanpa menganalisa terlebih dahulu dan menggunakan prosedur matematika/ konsep yang tidak relavan pada soal. S2b belum tepat dalam menghubungkan antara satuan besar sudut dan satuan waktu. Hal ini berarti S2b mengalami kesalahan tipe T.

Selain itu, S2b salah dalam mengerjakan runtutan penyelesaian soal dikarenakan prosedur yang dipilih siswa belum tepat (S1b-T5a2), hal ini berarti siswa mengalami kesalahan tipe P. S2b juga mendapatkan jawaban akhir yang kurang tepat (S2b-T3a3). Oleh karena itu, S2b mengalami kesalahan tipe E. 


\section{Domain Kognitif Penalaran(Reasoning)}

Soal TIMSS domain kognitif penalaran yang diujikan kepada setiap subjek yaitu mencari besara sudut tertentu dari gabungan dua bangun datar.

Soal 2.

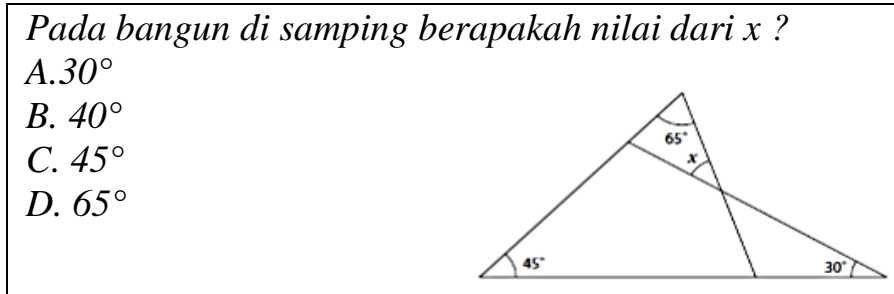

Pada soal 2, terdapat sebuah gambar dari gabungan 2 segitiga dan beberapa sudut yang ada pada segitiga tersebut. Sudut-sudut tersebut adalah $65^{\circ}, 45^{\circ}, 30^{\circ}$ dan $x$. Untuk menyelesaikan soal, dapat menggunakan rumus jumlah sudut segitiga, yaitu $180^{\circ}=65^{\circ}+45^{\circ}+30^{\circ}+x$.

\section{Subjek Kemampuan Awal Matematika Tinggi (S1a)}

Dalam menyelesaikan soal TIMSS dengan domain kognitif penalaran S1a mengalami beberapa jenis kesalahan.

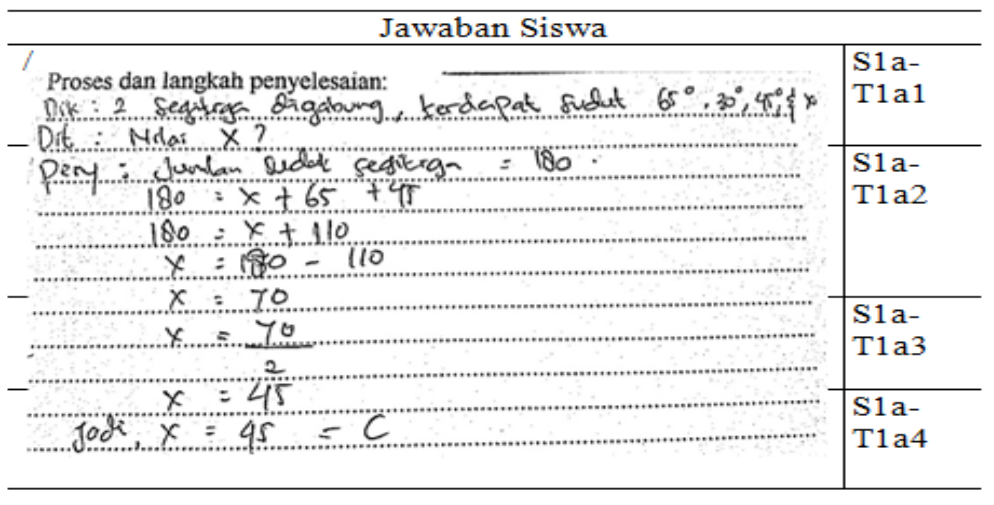

GAMBAR 4. Paparan hasil tes soal TIMSS untuk subjek S1a

Pada Gambar 4, terlihat S1a menggunakan prosedur dengan rumus jumlah sudut segitiga yaitu $180=x+65+45$ untuk menyelesaikan soal. Prosedur yang dipilih S1a belum tepat (S1a-T1a2). Hal ini dikonfirmasi pada Transkip 3.

\section{TRANSKIP 3}

$P$

S1a-Wla9

$P$

Sla-Wlalo Ehh, astaga kak salah ka pale, 35 harusnya. Ai salah jawabanku pale itu kalo 45 kak. Fokus ka kak dipilihan jawabannya

Pada Transkip 1, menunjukkan S1a menggunkan rumus jumlah sudut segitiga dengan memperhatikan 2 segitiga yang ada. S1a mengambil sudut $65^{\circ}, 45^{\circ}$, dan $\mathrm{x}$ untuk menyelesikan 
soal dengan alasan bahwa hanya sudut tersebut yang menghubungkan kedua segitiga tersebut. Kemudian menyelesaikan soal dengan menjumlahkan ketiga sudut terebut dan menganggap bahwa jumlah dari ketiganya sama dengan $180^{\circ}$. S1a cenderung secara langsung menggunakan suatu prosedur matematika tanpa menganalisa terlebih dahulu gambar pada soal sehingga algoritma/rumus yang digunakan belum tepat. Hal ini menunjukkan bahwa, S1a mengalami kesalahan tipe $\mathrm{T}$

Selain itu, S1a salah dalam melakukan operasi perhitungan yakni 70 dibagi 2 yang menghasilkan 45 (S1a-W1a10). Dalam menyelesaikan soal, S1a tidak menyadari kesalahannya. Sebenarnya S1a paham bahwa 70 dibagi 2 bukanlah 45 melainkan 35, namun karena S1a terlalu fokus terhadap pilihan jawaban yang akan diperoleh sehingga runtutan penyelesaian soal pun tidak tepat. Oleh karena itu, S1a mengalami kesalahan tipe P. Disamping itu, karena S1a mendapatkan jawaban akhir yang kurang tepat sehingga mengalami kesalahan tipe E.

\section{Subjek Kemampuan Awal Matematika Rendah (S2b)}

Dalam menyelesaikan soal TIMSS dengan domain kognitif penalaran, S2b mengalami beberapa jenis kesalahan kesalahan.

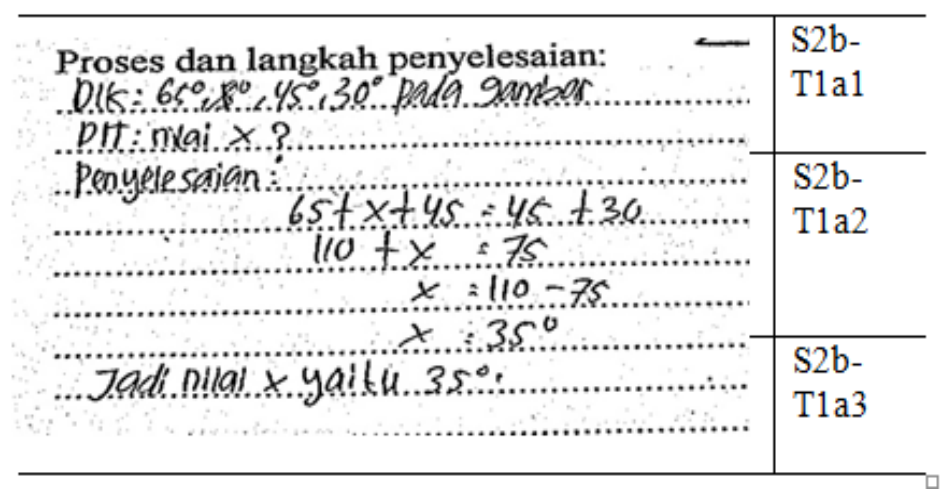

GAMBAR 5. Paparan hasil tes soal TIMSS untuk subjek S2b

Pada gambar 5, terliat S2b menuliskan hal yang diketahui dan ditanyakan namun belum tepat (S2b-T1a1). Hal tersebut dikonfirmasi pada wawancara Transkip 4.

\section{TRANSKIP 4}

$$
P
$$

$S 2 b-W 1 a 6$

$P$

S2a-W1a7

$P$

S2a-W1a8

$P$

$S 2 b-W 1 a 9$

$P$

$S 2 b-W 1 a 10$
Iya dek, coba apa yang diketahui dan ditanyakan dek?

Diketahui kak sudut $65^{\circ}, x, 45^{\circ}, 30^{\circ}$ pada gambar. Ditanyakan nilai $x$

Yakin dek hanya itu yang dietahui?

Gambarnya kak tidak ku tau ki bentuk apa

Hmm, Sekarang dek perhatikan coba gambarnya! Ini dek dengan yang ini, kira-kira gambar bangun datar apa? (menunjuk salah satu bentuk gambar)

Oh yang ini kak dilihat tapi tidak semua ki kak (mengerutkan kening)

Iya dek kita liat bede dulu garis ini adalah merupakan bentuk apa gambarnya?

Segitiga kak dua-duanya

Nah, jadi gambar ini adalah gabungan dari dua segitiga kan?

Iye kak

Pada Transkip 3, menujukkan S2b tidak bisa mengetahui apa yang diketahui dengan tepat terkait gambar yang disajikan pada soal (S2b-W1a7). Oleh karena itu, S2b tidak bisa memahami arti keseluruhan soal ( tidak menggunakan seluruh informasi pada soal dan mengabaikan informasi penting dalam soal) sehingga melakukan kesalahan tipe C. 
Selain itu, Gambar 5 menunjukkan prosedur yang dipilih S2b dengan operasi $65+x+45=45$ +30 belum tepat (S2b-T1a2). Setelah dikonfirmsi, S2b tidk mengetahui prosedur/ rumus apa yang akan digunakan. Hal tersebut dikonfirmasi pada wawancara Transkip 5:

\section{TRANSKIP 5}

$P$

Coba jelaskan dek bagaimana carata dapat jawabanta!

S2b-Wlall Tidak ku tau kak bagaimana selesaikan ki, saya tambah-tambah ji ini ka sudut yang ada disini, $65^{\circ}+x+45^{\circ}=45^{\circ}+30^{\circ}$

$P \quad$ Kenapa bisa ditamba-tambah begitu dek sudutnya

S2a-Wla12 Asal-asal ja kak, tidak ku tau seleaikan

$P \quad H m m$, jadi jawabanta dek bagaimana?

S2a-W1a13 Jadi nilai x yaitu $35^{\circ}$

Pada Transkip 5, terlihat S2b menggunakan prosedur yang belum jelas landasannya (S2bW1a11). S2b tidak mampu menganalisa terlebih dahulu gambar yang ada, lebih fokus pada keadaan nyata grafik/gambar daripada karakteristik grafik/gambar. Hal ini menunjukkan, S2b cenderung secara langsung menggunakan suatu prosedur matematika yang kurang tepat dan mengalami kesalahan tipe $\mathrm{T}$.

S2b juga salah dalam mengerjakan runtutan penyelesaian soal dikarenakan salah dalam menentukan prosedur penyelesaian yang tepat (S2a-W1a12). Oleh karena itu, S2b mengalami kesalahan tipe P. Jawaban akhir yang ditunjukkan S2b juga kurang tepat (S2b-T1a3). S2b juga mengalami kesalahan tipe $\mathrm{E}$.

\section{KESIMPULAN}

Perbedaan jenis kesalahan yang dialami siswa berkemampuan awal tinggi dan siswa berkemampuan awal rendah terlihat jelas. Untuk kesalahan yang dialami pada soal mengaplikasikan lebih sedikit dibandingkan dengan soal penalaran. Pada soal mengaplikasikan, kesalahan yang sering muncul yaitu tipe T, tipe P, dan tipe E. Kesalahan tersebut hanya dialami oleh siswa berkemampuan rendah. Sedangkan pada soal penalaran, kesalahan yang sering muncul hampir sama dengan soal mengaplikasikan. Hanya saja pada soal penalaran, kesalahan dialami oleh semua subjek. Kesalahan tersebut didominasi oleh siswa berkemampuan awal matematika rendah. Kesalahan yang muncul yaitu kesalahan tipe C, tipe T, tipe P, dan Tipe E.

TABEL 4. Perbedaan jenis kesalaan yang dialami siswa

\begin{tabular}{ccccc}
\hline \multirow{2}{*}{ Jenis } & \multicolumn{2}{c}{ Mengaplikasikan } & \multicolumn{2}{c}{ Penalaran } \\
\cline { 2 - 5 } Kesalahan & $\begin{array}{c}\text { Kemampuan } \\
\text { Tinggi }\end{array}$ & $\begin{array}{c}\text { Kemampuan } \\
\text { Rendah }\end{array}$ & $\begin{array}{c}\text { Kemampuan } \\
\text { Tinggi }\end{array}$ & $\begin{array}{c}\text { Kemampuan } \\
\text { Rendah }\end{array}$ \\
\hline $\mathbf{R}$ & - & - & - & - \\
$\mathbf{C}$ & - & - & - & $\sqrt{ }$ \\
$\mathbf{T}$ & - & $\sqrt{ }$ & $\sqrt{ }$ & $\sqrt{ }$ \\
$\mathbf{P}$ & - & $\sqrt{ }$ & $\sqrt{ }$ & $\sqrt{ }$ \\
$\mathbf{E}$ & - & $\sqrt{ }$ & $\sqrt{ }$ & $\mathrm{V}$ \\
\hline
\end{tabular}

Telah dipaparkan sebelumnya bahwa kesalahan yang paling sering muncul yaitu pada soal-soal penalaran. Untuk itu, dilakukan penelitian lanjutan mengenai analisis tingkat pemahaman dan miskonsepsi siswa dalam menyelesaikan soal matematika terutama pada soal-soal penalaran. Hal tersebut guna mengurangi kesalahan-kesalahan yang sering dialami siswa dalam menyelesaikan soal dan dapat meningkatkan prestasi belajar siswa. 


\section{DAFTAR PUSTAKA}

Abdullah, A.H., Abidin, N.L.Z., \& Ali, M. (2015). Analysis of Students Errors in Solving Higher Order Thinking Skills (HOTS) Problems for the Topic of Fraction. Canadian Center of Science and Education, 11(21): 133-142.

Depdiknas (2006). Permendiknas Nomor 22 Tahun 2006 tentang Standar Isi Sekolah Menengah Atas. Jakarta : Depdiknas.

Gunawan, H., \& Salim., A. (2010). Analisis Konten dan Capaian Siswa Indonesia dalam TIMSS (Trends in International Mathematics and Science Study) 1999, 2003, dan 2007. Jakarta : Pusat Penilaian Pendidikan, Badan Penelitian Dan Pengembangan Kementerian Pendidikan Nasional

Herlambang. (2013). Analisis kemampuan Pemecahan Masalah Matematika Siswa Kelas VII-A SMP Negeri 1 Kepahiang Tentang Bangun Datar Ditinjau Dari Teori Van Hiele. (Tesis) Universitas Bengkulu

Laeli, Hidayatullah. (2017). Deskripsi Kesalahan Siswa Kelas Vii Smp N 3 Kebasen Dalam Menyelesaikan Soal Operasi Hitung Bilangan Bulat. Purwokerto: FKIP UMP

Nurkhasanah, SW. (2016). Analisis Kesalahan Dalam Penyelesaian Soal Matematika Berbasis Timss Konten Geometri Pada Siswa Kelas VIII. Universitas Muhammadiyah. Surakarta

Pusat Penilaian Pendidikan Badan Penelitian Dan Pengembangan. (2015). TIMSS infographic. Indonesia : Kementerian Pendidikan dan Kebudayaan

Rosnawati, R. (2013). Kemampuan Penalaran Matematika Siswa SMP Indonesia pada TIMSS 2011. Disajikan dalam Seminar Nasional Penelitian, Pendidikan, dan Penerapan MIPA UNY, 18 Mei 2013, UNY Yogyakarta.

Singh, P., Rahman, A.A.,\& Sian Hoon, T. (2010). The Newman Procedure for Analyzing Primary Four Pupils Errors on Written Mathematical Task: A Malaysian Perspective. Procedia on International Conference on Mathematics Education Research 2010 (ICMER 2010), 8(2010): 264-271. Diakses pada 28 September 2018 (http://www.sciencedirect.com)

Wijaya, A. (2014). Difficulties in Solving Context-Based PISA Mathematics Task: An Analysis of Student Error. The Mathematics Enthusiast, 11(3): 555-584 